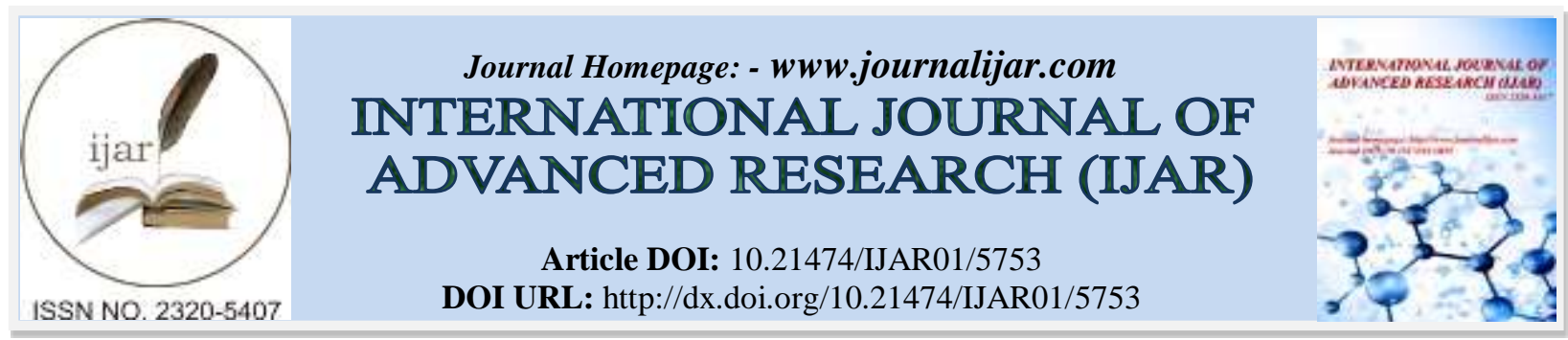

RESEARCH ARTICLE

\title{
PERCEIVED LONELINESS AND SOCIAL DISSATISFACTION AMONG CHILDREN OF WORKING AND NON- WORKING MOTHERS.
}

\author{
Manveer Rakkar ${ }^{1}$, Bharat Pareek $^{2}$ and Rupinder Kaur ${ }^{3}$. \\ 1. M.Sc Nursing $2^{\text {nd }}$ year, Student, Saraswati Nursing Institute, Kurali, Punjab. \\ 2. Associate Professor, Saraswati Nursing Institute, Kurali, Punjab. \\ 3. Lecturer, Saraswati Nursing institute, Kurali, Punjab.
}

\section{Manuscript Info \\ Manuscript History \\ Received: 03 September 2017 \\ Final Accepted: 05 October 2017 \\ Published: November 2017}

Key words:-

Adolescence, Perceived loneliness, Social dissatisfaction, Working mothers, Non-working mothers.

\begin{abstract}
Adolescence is a life period which includes major changes in young person's physical, social, emotional and cognitive growth and development. Loneliness is a distressing and common experience throughout the adolescence. A cross-sectional comparative survey study was conducted to assess and compare perceived loneliness and social dissatisfaction among children of working and non-working mothers. Total 200 children of working and non-working mothers residing in urban areas of Kurali were selected by networking sampling technique. UCLA-Loneliness scale (Standardized) and Social dissatisfaction assessment scale (self-development) was used to collect data from the study participants. Study revealed that the overall level of perceived loneliness among children of working and non-working mothers was at moderate level with mean percentage of $38.6 \%$ and $36.05 \%$ respectively and observed statistically non-significant ( $>0.05$ ). Children of working mothers had slightly higher level (Mean $\%=57.6 \%)$ of social dissatisfaction as compared to children of nonworking mothers $($ Mean\%=56.9\%) which was statistically nonsignificant $(p>0.05)$. Study concluded that overall level of perceived loneliness and social dissatisfaction among children of working and non-working mothers was at moderate level and mothers working status (working and non-working) does not affect perceived loneliness and social dissatisfaction among their children.
\end{abstract}

Copy Right, IJAR, 2017,. All rights reserved.

\section{Introduction:-}

Women plays dual role in life. At home, they play the role of mother and at workplace they play the part of an employer. A mother is particularly important not because she has special skills but because she is with her children for a much greater time than any other person and her instructions reflects a very strong influence on attitudes, abilities and behavior of children. Most of those children who are successful and well-adjusted come from homes where parental attitudes are favorable and a wholesome relationship exist between children and parents. Mother gives her children love, affection and care since birth. Child-care has become a major issue in most of the countries of the world. It is a universal truth that children require the love of mother the most. ${ }^{1}$ 
Working women may not be able to provide care with the same intensity to their children as non-working women. This results in development of behavioral problems in children of working mothers. They feel lonely, become awkward, absent minded, develop inferiority complex, become aggressive, attention deficit hyperactive, nervous, cognitively fatigued, become shy, fearful, develop bad habits as lying, stealing etc. as there was no one to shape their behaviors in an appropriate way. This working status of mother can affect a child's development and can interfere with their ability to adjust themselves to lead a normal life. These kinds of problematic behaviors of children put a huge strain on family as well as on the society. ${ }^{2}$

Research focusing upon loneliness and isolation in children is increasing rapidly, and there is evidence that loneliness is predictive of later adjustment problems. Children who are socially isolated or rejected by their peers appear to be at risk for academic failure, juvenile delinquency, mental health problems and substance use. ${ }^{3}$

\section{Objectives:-}

1. To compare the perceived loneliness among children of working and non-working mothers by using UCLALoneliness Scale.

2. To compare the social dissatisfaction among children of working and non-working mothers by using Social Dissatisfaction Assessment Scale.

\section{Hypothesis:-}

$\mathbf{H}_{01}$ :-There is no significant difference in perceived loneliness among children of working and non-working mothers at 0.05 level of significance.

$\mathbf{H}_{\mathbf{0 2}}$ :-There is no significant difference in social dissatisfaction among children of working and non-working mothers at 0.05 level of significance.

\section{Methodology:-}

Cross-sectional descriptive, comparative survey design was adopted to compare the perceived loneliness and social dissatisfaction among children of working and non-working mothers. The conceptual framework used to guide the study was "The Stuart Adaptation Model of Psychiatric Nursing" Children of working and non-working mothers (12-17 years age) were selected from urban areas of Kurali through network sampling. Power analysis was used to estimate in advance how big a sample is needed for the survey. A total of 200 samples (100 children of working and 100 children of non-working mothers respectively) were drawn.

Study tools were prepared in English and Punjabi that composed of three parts. Part1: consists of five items to collect information of sample characteristics. Part 2: consists of UCLA-loneliness scale (standardized scale) to assess the perceived loneliness level of children. A continuum of high score response was designed for each statement in the entire scale as often $=3$, sometimes $=2$, rarely $=1$ and never $=0$. Part 3: consists of Social dissatisfaction assessment scale (self-developed) where each statement in the entire scale designed as always true= 4 , true most of the time $=3$, true sometimes $=2$, hardly ever true $=1$ and never $=0$. Six experts from psychiatric nursing and one expert from community health nursing determined the content validity of the tools. Reliability (internal consistency and stability) of the both scales was determined by administering the study tools to 20 children of working and non-working mothers. Cronbach's Alpha was used where the internal consistency of UCLA-loneliness scale and social dissatisfaction assessment scale were $\mathrm{p}=0.85$ and 0.75 respectively which were found to be reliable. The Stability of the both scales were also determine using test -retest method. The stability of UCLA-loneliness scale and social dissatisfaction assessment scale were obtained $\mathrm{p}=0.78$ and 0.85 respectively which was found to reliable.

Ethical clearance to conduct study was obtained from institutional ethics committee (IEC) of Saraswati Nursing Institute. A Pilot study was conducted to determine the feasibility of the actual study and also to determine sample size. All the methodological decisions were evaluated and found to be feasible hence no changes were made in the main study. The permission for data collection obtained from the concern authority, the investigator assured the anonymity to the subjects, and their consent obtained. The data collected during the month of January. Data was collected from the urban areas of Kurali. Data was analyzed with the help of SPSS (Version 20). Appropriate descriptive (mean, median, standard deviation) and inferential statistics (chi-square, t-test) were used. 


\section{Results:-}

Table 1:- Frequency distribution of subjects according to Age, Gender, Education, Type of School, Sibling (N= 200)

\begin{tabular}{|c|c|c|c|c|c|c|}
\hline \multirow{2}{*}{\multicolumn{2}{|c|}{$\begin{array}{c}\text { Socio-demographic } \\
\text { Variables }\end{array}$}} & \multicolumn{3}{|c|}{ Subjects } & \multirow{3}{*}{$\mathrm{Chi}^{2}$} & \multirow{3}{*}{ p-value } \\
\hline & & \multirow{2}{*}{$\begin{array}{c}\begin{array}{c}\text { Working } \\
\text { Mothers }\end{array} \\
\text { f }(\%)\end{array}$} & $\begin{array}{c}\text { Non-Working } \\
\text { Mothers }\end{array}$ & \multirow{2}{*}{$\begin{array}{l}\begin{array}{l}\text { Total } \\
(\mathrm{N}=\mathbf{2 0 0})\end{array} \\
\mathbf{f}(\%) \\
\end{array}$} & & \\
\hline \multirow{3}{*}{$\begin{array}{l}\text { Children's } \\
\text { Age( in years) }\end{array}$} & & & & & & \\
\hline & $=-15$ & $43(43.0)$ & $54(54.0)$ & $97(48.5)$ & \multirow[b]{2}{*}{2.00} & \multirow[b]{2}{*}{$0.00 *$} \\
\hline & $>=16$ & $57(57.0)$ & $46(46.0)$ & $103(51.5)$ & & \\
\hline \multirow[t]{2}{*}{ Gender } & Male & $53(53.0)$ & $65(65.0)$ & $118(59.0)$ & \multirow[b]{2}{*}{2.976} & \multirow[b]{2}{*}{0.08} \\
\hline & Female & $47(47.0)$ & $35(35.0)$ & $82(41.0)$ & & \\
\hline \multirow{2}{*}{$\begin{array}{l}\text { Children's } \\
\text { Education }\end{array}$} & $6-8$ & $27(27.0)$ & $31(31.0)$ & $58(29.5)$ & \multirow[b]{2}{*}{.389} & \multirow[b]{2}{*}{0.53} \\
\hline & $9-12$ & $73(73.0)$ & $69(69.0)$ & $142(71.0)$ & & \\
\hline \multirow[t]{2}{*}{ Type of school } & Single & $11(11.0)$ & $17(17.0)$ & $28(14.0)$ & \multirow[b]{2}{*}{1.492} & \multirow[b]{2}{*}{0.22} \\
\hline & Co-ed & $89(89.0)$ & $83(83.0)$ & $172(86.0)$ & & \\
\hline \multirow[t]{5}{*}{ Siblings } & No & $7(7.0)$ & $3(3.0)$ & $10(5.0)$ & \multirow{5}{*}{6.543} & \multirow{5}{*}{0.16} \\
\hline & One & $26(26.0)$ & $39(39.0)$ & $65(32.5)$ & & \\
\hline & Two & $28(28.0)$ & $31(31.0)$ & $59(29.5)$ & & \\
\hline & Three & $25(25.0)$ & $17(17.0)$ & $42(21.0)$ & & \\
\hline & More than three & $14(14.0)$ & $10(10.0)$ & $24(12.0)$ & & \\
\hline
\end{tabular}

*= Significant

Table 1 depicts that Majority (51.5\%) of children belongs to age $\Rightarrow 16$ whereas $48.5 \%$ children belongs to age $=<15$. Among the subjects, $59 \%$ were males whereas $41.2 \%$ were females. Majority $(71 \%)$ children were studying in 9-12 class whereas $29.5 \%$ were studying in 6-8 class. Almost half of $86 \%$ children studying in co-ed school whereas $14 \%$ studying in single school. Of the total 5\% subjects do not have any siblings, $12 \%$ have more than three siblings, $21 \%$ have three siblings, $29.5 \%$ have two siblings and $32.5 \%$ have only one sibling.

Chi-square test was used to check homogeneity of socio-demographic variables among subjects. The results revealed that children age (in years) were found to be heterogeneous whereas gender, children's education, type of school, siblings were homogeneous at $\mathrm{p}<0.05$.

Table 2:-Assessment and Comparison of the perceived loneliness and social dissatisfaction among children of working and non- Working Mothers $(\mathrm{N}=200)$

\begin{tabular}{|c|c|c|c|c|c|}
\hline \multirow{3}{*}{$\begin{array}{c}\text { Perceived } \\
\text { Loneliness }\end{array}$} & Group & Mean \pm SD & Mean \% & t-value & p-value \\
\hline & Working mothers & $23.16 \pm 11.13$ & $38.6 \%$ & \multirow[b]{2}{*}{.992} & \multirow[b]{2}{*}{.323} \\
\hline & $\begin{array}{c}\text { Non-working } \\
\text { mothers }\end{array}$ & $21.63 \pm 10.68$ & $36.05 \%$ & & \\
\hline \multirow{2}{*}{$\begin{array}{c}\text { Social } \\
\text { Dissatisfaction }\end{array}$} & Working mothers & $71.92 \pm 11.2$ & $57.5 \%$ & \multirow[b]{2}{*}{.438} & \multirow[b]{2}{*}{.662} \\
\hline & $\begin{array}{c}\text { Non-working } \\
\text { mothers }\end{array}$ & $71.20 \pm 12.04$ & $56.9 \%$ & & \\
\hline
\end{tabular}

Table 2depicts that Mean \pm SD score of loneliness among children of working mothers was $23.16 \pm 11.13$ with mean percentage of $38.6 \%$ whereas Mean \pm SD score of loneliness among children of non-working mothers was $21.63 \pm 10.68$ with mean percentage of $36.05 \%$ respectively. Further table revealed that children of working mothers experienced more perceived loneliness than children of non-working mothers and observed statistically nonsignificant. ( $p>0.05)$ In social dissatisfaction, Mean \pm SD score among children of working mothers were $71.92 \pm$ 12.04 with the mean percentage of $57.5 \%$ whereas Mean \pm SD score of social dissatisfaction among children of working mothers were $71.20 \pm 11.2$ with the mean percentage of 56.9\% respectively. The result revealed that children of working mothers had little dissatisfaction in society as compared to children of non-working mothers and observed statistically non-significant $(\mathrm{p}>0.05)$ 


\section{Discussion:-}

Findings revealed that No significant difference between perceived loneliness among working and non-working mothers. The Mean \pm SD score of loneliness among children of working mothers was $23.16 \pm 11.13$ with mean percentage of $38.6 \%$ whereas Mean \pm SD score of loneliness among children of non-working mothers was $21.63 \pm 10.68$ with mean percentage of $36.05 \%$ respectively. Similar study done by Aggarwal S. (2016) ${ }^{4}$ revealed that children of working mothers were less emotionally stable as compared to those of nonworking mothers. The children of non-working women found to be more active, enthusiastic, assertive, trusting \& non depressive.

Study done by Khan M.A., Shah R., (2015) ${ }^{5}$ indicated that children of non-working mothers are emotionally mature and stable than children of working mothers. Study conducted by Alexander A., Shetty P A (2014) ${ }^{\mathbf{6}}$ revealed that there was mild level of behavioral problems reported by $40 \%$ of children of working and $83.3 \%$ of children of nonworking mothers, whereas moderate level of behavioral problems reported by $16.7 \%$ of non-working and $60 \%$ of working mothers. Present study revealed that there is no significant difference of children of working and nonworking mothers in terms of perceived loneliness and social dissatisfaction. These findings are inconsistent with study done by Soumita Ranjan (2013) ${ }^{2}$ where she reported that children of working mothers show more behavioral problems as compared to those of non-working mothers.

Findings revealed that $11.5 \%$ of mothers were illiterate, $22.5 \%$ were having primary education, $35 \%$ were secondary education , 21\% were higher secondary whereas $10 \%$ mothers were graduates and above. Similar study done by Masood S., Tariq T. (2011) ${ }^{7}$ revealed that children of less educated mothers experienced significantly more feelings of loneliness as compared to the children of highly educated mothers. Study by Tamer, S.K., Mehta, P.K., Warey, P.et al (1986) ${ }^{\mathbf{8}}$ revealed that children of working mothers have significantly higher psychological problem as compared to others.

These results are contradictory with the findings of present study where two variables (perceived loneliness and social dissatisfaction) were assessed and no significant difference observed between children of working and nonworking mothers even though the level of social dissatisfaction was little higher among children of working mothers.

\section{Conclusion:-}

Loneliness is an unpleasant feelings that arises due to discrepancy between desired and achieved quality of one's social network, and has a deleterious effects on various aspects of psychological wellbeing. Loneliness is very distressing and common experience throughout adolescence. It is period in which adolescents lack definite coping skills. A study concluded that no significant difference were observed between children of working and nonworking mothers in terms of perceived loneliness and social dissatisfaction ( $p>0.05)$. Parents, teachers and nurses should enhance the family and school environment conducive to reduce the level of perceived loneliness and social dissatisfaction. Education, guidance and counselling services can be promoted to mould the behavior of children towards environment.

\section{Conflict of Interest:-}

The study entitled "Perceived Loneliness And Social Dissatisfaction Among Children Of Working And NonWorking Mothers" is the self funded research work of Miss Manveer Rakkar and authors have declared no conflict of interest.

\section{References:-}

1. Almani A.S., Abro A., Mugheri A.Study of the Effects of Working Mothers on the Development of Children in Pakistan. International Journal of Humanities and Social Science.2012. 2(11):164-171.Available from: http://www.ijhssnet.com/journal /index/ 1047

2. Ranjan S. Effect of Mother's Working Status on Behavioral Problems of Primary School Children. An International Journal of Education. 2013. 3(2): 36-41.

3. Randy M, Children feelings of loneliness and social dissatisfaction relation to physical fitness and activity, Journal of Teaching in Physical Education 1992: 211-219.

4. Aggarwal S. Personality traits in children of working and non-working mothers: Comparative study. Scholarly Research journal for interdisciplinary studies. May-June 2016. 3(24); 2212-2216. Available from: www.srjis.com 
5. Khan M.A., Shah A., Emotional maturity of children of working and non-working mothers- A comparative study. Indian journal of educational research studies. Sep-Oct 2015. 1(3); 223-233. Available from: www.srjis.com.

6. Alexander A., Shetty P.S. A Comparative Study on Behavioral Problems of Preschool Children among Working and Non-Working Mothers IOSR Journal of Nursing and Health Science .2014.3(6); 35-38.Available from: www.iosrjournals.org.

7. Tariq T, Masood S. Social Competence, Parental Promotion of Peer Relations, and Loneliness among Adolescents .Pakistan Journal of Psychological Research. 2011. 26 (2):217-232.

8. Tamer, S.K., Mehta, P.K., Warey, P. et al. A study on working educated mothers and its impact on child health. Indian Journal of Pediatric Sep 1986. 53 (5): 657- 663. Available from: http://dx.doi .org/10.1007/BF02748675. 